\title{
Effects of Use of Information and Communication Technologies (ICTs) on Farmers' Agricultural Practices and Welfare in Orlu Agricultural Zone of Imo State, Nigeria
}

\author{
${ }^{1}$ Chikaire, J.U., ${ }^{1}$ Anyoha, N.O., ${ }^{1}$ Anaeto, F.C. and ${ }^{2}$ Orusha, J.O. \\ ${ }^{I}$ Dept. of Agricultural Extension, Federal University of Technology, Owerri, Imo State, Nigeria \\ ${ }^{2}$ Dept. of Agricultural Education, Alvan Ikoku Federal College of Education Owerri, Imo State., Nigeria \\ Email: symeonjachin@gmail.com
}

\begin{abstract}
The aim of this study was to ascertain the effects of use of Information and Communication Technologies (ICTs) on farmers' agricultural practices and welfare in Orlu Agricultural Zone, Imo State. Data were collected with structured questionnaire distributed to 130 respondents randomly selected from the 10 extension blocks in Orlu Agricultural Zone. Percentages, bar graph, mean scores, standard deviation, presented in frequency table and Likert type scale were used to analyze the data. The result obtained showed that ICT devices available in the area included radio, mobile phones, television, and newspapers among others. However, radio is the most readily available ICT device $(99.2 \%)$, followed by mobile phone $(97.7 \%)$. It was also observed that ICTs have significant effects on the farmers', agricultural practices and welfare as indicated by a high mean score on the statements.. Several factors constrained the use of ICT devices. Among these factors were; erratic power supply (98.5\%), low level of education (93.1\%), language barrier (92.3\%), lack of ICT skills (91.5\%), low income of farmers $(88.5 \%)$, unavailability of ICT centers $(82.3 \%)$ and high cost of ICT facilities $(79.2 \%)$. This study thus recommended that Government should provide financial support to farmers through the provision of interest free loans to enable them acquire and use the technologies. Government should improve rural infrastructures particularly electricity supply in the study area. The rural dwellers should be given the requisite skills required for information management. They should be exposed to practical computer training for the enhancement of ICT use.
\end{abstract}

Keywords: ICTs, farmers, welfare, agriculture, Nigeria

\section{INTRODUCTION}

Agriculture is a vital sector for the sustained growth of developing countries, especially agriculturebased countries such as those in sub-Saharan Africa. Equally important, a significant portion of the world's population - 86 percent of rural inhabitants - still depends on agriculture for employment and sustenance (World Bank, 2007). Demand for food is increasing, too. The Food and Agricultural Policy Research Institute (FAPRI) estimates that an additional 6 million hectares of maize and 4 million hectares of wheat plus a 12 percent increase in global maize and wheat yields will be needed to meet demand for cereals alone in the next decade (Edgerton, 2009). Demand for meat is expanding as incomes rise, creating competition for land and other resources. Increasingly unstable weather and temperatures require adaptive agronomic techniques to meet the demand.

Agriculture is the predominant activity in most of the zones in Nigeria, percentage of persons working in agriculture ranges between 24.4 and 85.1 percent across zones in Nigeria. With respect to states, the activity ranges between 2.4 and 91.7 per cent, majority of states having over 50 percent (CBN, 2000). Increases in agricultural output brought about by increasing land and labour productivity, will make food cheaper; benefit both rural and urban poor people who spend much of their income on food. Under right condition, increase in agriculture productivity causes the incomes of both small and large farmers to increase and generate employment opportunities. These increases in income is particularly important because the proportion of people mainly dependent on agriculture for their income remains high; ranging from 45\% in East and South Asia, to 53.2\% in Asia and 63.5\% in SubSaharan Africa (Ogen, 2007). The agricultural sector has a traditional role to play in the path of economic development. But in an economy like Nigeria, the agricultural sector had suffered set back in recent times, which has attributed to widespread poverty and insecurity experienced today. Though, 
Chikaire, J.U et al. "Effects of Use of Information and Communication Technologies (ICTs) on Farmers' Agricultural Practices and Welfare in Orlu Agricultural Zone of Imo State, Nigeria"

no so-called developed nation today actualized this status solely by agricultural transformation, but in many, conscious efforts on agriculture at the early stage of development played a critical role in economic development. Increasing productivity will bring about increased incomes of the farmers and non-farmers, because the proportion of people nearly directly or indirectly involved in agriculture and agricultural products for their income remains extremely high. Therefore, the provision of basic agricultural information is aimed at increasing the efficiency of agricultural markets and income for improved farmers' welfare.

Information and communication technologies (ICTs) play inevitable roles in every aspect of human activities today, including agriculture. The key players in agriculture are the farmers, and their ability to use the technologies defines the role of ICT in agriculture generally (Nwagwu and Opeyemi, 2015). ICT use by farmers is now on the increase globally. In increasing access and exchanging of information, ICT offer the potential to increase efficiency, productivity, competitiveness and growth in various aspects of agricultural sector. Farmers that engage in commercial agriculture in large scale might be expected to be using cameras, computing devices, digital imaging, the Internet and Wide Area Networking (WAN), Wi-Fi, SMS services, WAP (Wireless Access Protocol) based internet access using cellular telephony, and digital media and DVD, among others (Nwagwu and Opeyemi,2015). Those that engage in agriculture in small scale utilize various other forms of ICT such as mobile phones, computers, and the internet etc.

According to Munyua (2008), Information and knowledge play a central role in rural agricultural development. In emphasizing the role of information and knowledge, information and knowledge is described as prime productive resources. The Food and Agriculture Organization of the United Nations (2000) advances a corresponding view to this perspective in its assertion that "information and knowledge play a key role in ensuring food security and sustainable development". World Bank (2002, cited in International Institute for Communication and Development (IICD), 2006), also takes the position that "information and Communication technologies are a key input for economic development and growth". Information and communication technologies are key enablers of globalization. They allow for the efficient and cost-effective flow of information, products, people and capital across national and regional boundaries. ICT is not a panacea for rural development problems, but it has the potential to help the rural people to leaping some of the traditional barriers to development, by improving access to information, expanding the market base, enhancing employment opportunities and making government services work better (Swanson \&Rajalathi, 2010).

Historically, agricultural service delivery in developing countries started with production-oriented limited extension services for export crops. The attention was diverted in the fifties to food production and improved farming techniques (Anandajayasekeram, 2008). It is widely accepted that ICT is an important element within the array of market and non-market entities and agents that provide human capital enhancing inputs, as well as flow of information that can improve farmers' and other rural peoples' welfare. ICT is widely expected to be a useful tool contributing to development around the world (UNDP, 2005). It is also found that ICT allows efficient and transparent storage, processing and communication of information and that entrepreneurial innovation in this field may affect economic and social change (Kaushik, 2004). According to (Richardson, 1997), ICT kiosks, ICT-equipped intermediary organizations and mobile phones are expected to play an important role in strengthening the more complex and time-urgent pathways of information and knowledge-sharing on which agricultural innovations depend.

Given that the future of food depends to such a great extent on small-scale agriculture, governments and development partners are focusing on how to increase productivity in sustainable ways through new technologies that smallholders can use. Irrigation management, biotechnologies, pest management and eradication, soil assessment, improved nutrient and land management, improved market access, and innovative storage facilities are all strategies for increasing smallholders' agricultural productivity and improving their access to markets, but the challenge lies in ensuring that smallholders can obtain and use them. ICT provides an incredible opportunity to reach farmers with the technical information they require to increase yields. Good farming practices maximize chances of a good harvest. In the past, conventional farming practices treated entire farms as homogeneous units even though they are often variable in productive potential. This view is changing as technology allows producers to measure soil nutrient status, crop potential, pasture health, and water-use efficiency at specific sites within a field. ICTs like digital soil maps provide extensive soil 
Chikaire, J.U et al. "Effects of Use of Information and Communication Technologies (ICTs) on Farmers' Agricultural Practices and Welfare in Orlu Agricultural Zone of Imo State, Nigeria"

information that can be stored and accessed online. GPS, satellite imagery, remote sensors, and aerial images help to assess soil and land variations, and mobile applications and the Internet can disseminate the information quickly. Therefore, in the study area, the above is not known and the information on effects of use of ICTs on farmers' agricultural practices and their welfare is yet to be established and this is why this study was carried out. The main objective of this study is to determine the effects of use of Information and Communication Technologies (ICTs) on farmers' agricultural practices and welfare in Imo State, Nigeria. The specific objectives of this study include to:

i. describe the socio-economic characteristics of the farmers in the study area;

ii. identify ICT devices available to the farmers;

iii. determine the effects of use of ICTs on farmers' welfare and agricultural practices;

iv. identify perceived constraints facing the respondents' use of ICT devices.

\section{METHODOLOGY}

The study was carried out in Orlu Agricultural zone of Imo state. The state is in South-east Nigeria. Imo state is divided into three (3) senatorial districts of Owerri, Orlu and Okigwe politically and demarcated along three Agricultural Zones namely; Okigwe, Owerri and Orlu (IMSG,2001). The state is made up of twenty-seven (27) Local Government Areas (LGAs) and its capital is Owerri. Orlu Agricultural Zone is made up of eleven (11) LGAs. Imo state lies within latitudes $4{ }^{0} 45 \mathrm{~N}$ and $7^{0} 15 \mathrm{~N}$ and longitudes $6^{0} 50^{\circ} \mathrm{N}$ and $7^{0} 25^{\circ} \mathrm{E}$ with an area of around $5,100 \mathrm{sq} / \mathrm{km}$. It is bordered by Abia State on the East, by the River Niger and Delta State on the West, by Anambra State to the North, and River State to the South (IMSG, 2001). The estimated population of Imo State as of 2016 was 4.8million and the population density varies from 230-1,400 people per square kilometer (NPC, 2006). It lies within the tropical rain and evergreen forest with a tropical climate that is humid all year round. The rainy season spans from March to October and is bimodal with a two-week break in rainfall in August (August break). The main annual rainfall in the state is $20,00 \mathrm{~m}$ while the annual temperature is between $25^{\circ} \mathrm{C}$ and $28^{\circ} \mathrm{C}$ with relative humidity of about $98 \%$ during the raining season and between $50 \%$ and $60 \%$ during dry season. The major arable crops grown are cassava, yam, plantain/banana, maize, melon, sweet potato and vegetables such as okra, pepper, tomato and telfairia. Orlu agricultural zone has 10 Extension blocks and 107 extension circles manned by extension agents. All ICT user farmers in the zone constitutes the population of the study. A list of all registered ICT user farmers in the zone was obtained from ADP office in the zonal headquarters. The list has a total number of 1,300 ICT user farmers and $10 \%$ of the total number was randomly selected which gave a total sample size of 130 ICT user farmers. The study made use of both primary and secondary data. The primary data were collected from field investigation or survey using structured questionnaires and interview schedule. Secondary data sources were utilized to provide background information and other necessary to achieve some objectives of the study. Such secondary data includes textbooks, reports, journals, publications and proceedings. Enumerators were trained and used. Basically, data were analyzed using descriptive statistical tools such as mean, standard deviation, and percentages. This was used to analyze objectives 1, 2, 3. A four (4) point Likert type scale of Strongly Agreed (SA), Agreed (A), Disagreed (D) and Strongly Disagreed (SD) assigned values of 4, 3, 2 and 1 was used to analyze objectives 3 and 4 which is mathematically represented as:

$$
\frac{4+3+2+1}{4}=\frac{10}{4}=2.50
$$

Therefore, a mean of 2.50 and above was adjudged okay and accepted while any value below 2.50 was not accepted.

\section{RESULTS AND DISCUSSIONS}

\section{Socioeconomic Characteristics of Respondents}

The socioeconomic characteristics of the respondents investigated in this study included; Sex, Age, Major occupation, Educational attainment, Marital status, Farm size, household size, Membership of social organization, No of organizations belonged and their monthly income level. Table 1 showed that $55.4 \%$ of the respondents were males while $44.6 \%$ were females. This implies that both the males and the females are involved in agriculture in the area but the greater percentage of the male could be attributed to the dominance of the male folks in agriculture and related business as owners of land and 
Chikaire, J.U et al. "Effects of Use of Information and Communication Technologies (ICTs) on Farmers' Agricultural Practices and Welfare in Orlu Agricultural Zone of Imo State, Nigeria"

as family heads who take decisions for the family. Fig. 2 shows the distribution of respondents according to their age. The result obtained showed that the respondents with the highest percentage (30.0\%) were within the age bracket of 51-60. In the same vein, $27.7 \%$ and $26.2 \%$ of the respondents were within the age range of 41-50 and 61-70 respectively. The figure further showed that only $13 \%$ of the respondents were within the age range of 31-40, while the least percentage of the respondents with $3.1 \%$ were above 70 . The mean age was 53 years. It implies that majority of the respondents are still in their middle age. They are active to perform farm operations and have the capacity to search for relevant information required to do well in their agribusiness.

Entries in the table above showed that the occupation of the respondents were mostly farming with $59.2 \%$ followed by trading with $15.4 \%$. Also, $13.8 \%$ of the respondents were self-employed, while $11.5 \%$ were civil servants. It further shows that only $3.8 \%$ of the respondents engaged in other forms of occupation besides the named ones. Data from table 1 indicated that $47.7 \%$ of the respondents had secondary education, $29.2 \%$ had primary education, and $11.5 \%$ had tertiary education, while $10.0 \%$ had adult education. Only $1.5 \%$ of the respondents as shown in the table had no formal education. This implies that the respondents in the area of study acquired the basic education needed for better understanding and usage of ICT devices that will enable them to enhance productivity. This sample thus, is a literate sample. This tells why the farmers are information conscious and can manipulate ICT devices. It agrees with Asiabaka (2002) that the resultant effect of lack of education is resistance to change especially in the spread of information on agricultural innovation that are meant to change the lives of farmers positively.

Again, majority (76.2\%) of the respondents were married, $13.1 \%$ of them were widowed and $4.6 \%$ divorced. On the other hand, only $6.2 \%$ of the respondents were single. This indicates that the respondents in the study area were mainly married people. Table 1 showed also that the highest number of the respondents (50.0\%), had farm size within 0.5-1.0 hectare, this is followed by $39.2 \%$ of the respondents having farm size within 1.5-2.0 hectare, while $10.7 \%$ of the respondents have farm size above 2.5-3.0ha.. The mean of the farm size is 1.4ha. This indicates that the respondents are small scale farmers with little cultivable lands which are gotten mostly through inheritance.

Most of the respondents (62.3.\%) had a household size of 5-8, followed by $25.4 \%$ of the respondents having a household size less than 5 , while, only $12.3 \%$ had household size above 8 . The mean household size was 6.0 persons. This implies that the household distribution is large, as such, provides more labour for farming and large household size may also help to access more agricultural information. Figure 1 result showed that majority of the respondents $(75.4 \%)$ belonged to one social organization or the other, while $24.6 \%$ of them do not belong to any social organization. Farmers belong to and participate in associations or social groups in order to relate and interact with their fellow farmers and also get and share information among themselves. It is also believed that when they participate in their organizations and associations, they are likely to acquire leadership potential that can help them in disseminating information on important techniques or innovation and also have good administrative structure within the organization. The respondents who also play leadership role in those organizations are likely to be exposed to important information related to farm innovation and would adopt more innovation than their counterparts due to group dynamics effects (Asiabaka, 2002).

The table showed also that $24.6 \%$ of the respondents did not belong to any organization, greater percentage $(64.4 \%)$ belonged to one or two organizations, while only $10.8 \%$ belonged to three or more organizations. This indicates that, majority of the respondents are members of at least one organization. This could be attributed to the fact that, since the farmers must be informed or learned in in order to manipulate ICT devices, they thus belong to and participate in organizations so as to get and also share knowledge and information together. Greater proportion $(60.0 \%)$ of the respondents earned between $\$ 21,000$ to 40,000 , followed by a proportion of $25.4 \%$ who earned between $\$ 41,000$ to 60,000 , while $9.2 \%$ earned below $\$ 21,000$. Also, only $5.4 \%$ of the respondents earned above $\$ 60,000$. The mean income was $\$ 31,000$. The result shows that $30.8 \%$ of the respondents who earned above $\$ 40,000$ could readily afford three square meals per day, train their children in schools and also afford most ICT facilities than the greater percentage (69.2\%) of the respondents who earned from $\$ 40,000$ below.

Table1. Socioeconomic Characteristics of Respondents

\begin{tabular}{|l|l|l|}
\hline Attribute & Frequency & Percentage (\%) \\
\hline Sex & \\
\hline
\end{tabular}


Chikaire, J.U et al. "Effects of Use of Information and Communication Technologies (ICTs) on Farmers' Agricultural Practices and Welfare in Orlu Agricultural Zone of Imo State, Nigeria"

\begin{tabular}{|c|c|c|}
\hline Male & 72 & 55.4 \\
\hline Female & 58 & 44.6 \\
\hline \multicolumn{3}{|l|}{ Income $(\mathbf{N})$} \\
\hline$<21,000$ & 12 & 9.2 \\
\hline $21,000-40,000$ & 78 & 60.0 \\
\hline $41,000-60,000$ & 33 & 25.4 \\
\hline Above 60,000 & 7 & 5.4 \\
\hline \multicolumn{3}{|l|}{ Marital Status } \\
\hline Single & 8 & 6.2 \\
\hline Married & 99 & 76.2 \\
\hline Divorced & 6 & 4.6 \\
\hline Widowed & 17 & 13.1 \\
\hline \multicolumn{3}{|l|}{ Household size } \\
\hline $1-4$ & 33 & 25.4 \\
\hline $5-8$ & 81 & 62.3 \\
\hline Above 8 & 16 & 12.3 \\
\hline \multicolumn{3}{|c|}{ Education level } \\
\hline Adult school & 13 & 10.0 \\
\hline Primary & 38 & 29.2 \\
\hline Secondary & 62 & 47.7 \\
\hline Tertiary & 15 & 1.5 \\
\hline No formal & 2 & \\
\hline \multicolumn{3}{|c|}{ Major Occupation } \\
\hline Farming & 77 & 59.2 \\
\hline Trading & 20 & 15.4 \\
\hline Self-employed & 18 & 13.8 \\
\hline Civil servant & 15 & 11.5 \\
\hline \multicolumn{3}{|l|}{ Farm size } \\
\hline $0.5-1$ & 65 & 50.0 \\
\hline $1.5-2$ & 51 & 39.2 \\
\hline $2.5 \&$ above & 14 & 10.7 \\
\hline \multicolumn{3}{|c|}{ Farming Experience } \\
\hline $1-20$ & 14 & 11.7 \\
\hline $20-40$ & 80 & 66.7 \\
\hline $40 \&$ above & 26 & 21.6 \\
\hline
\end{tabular}

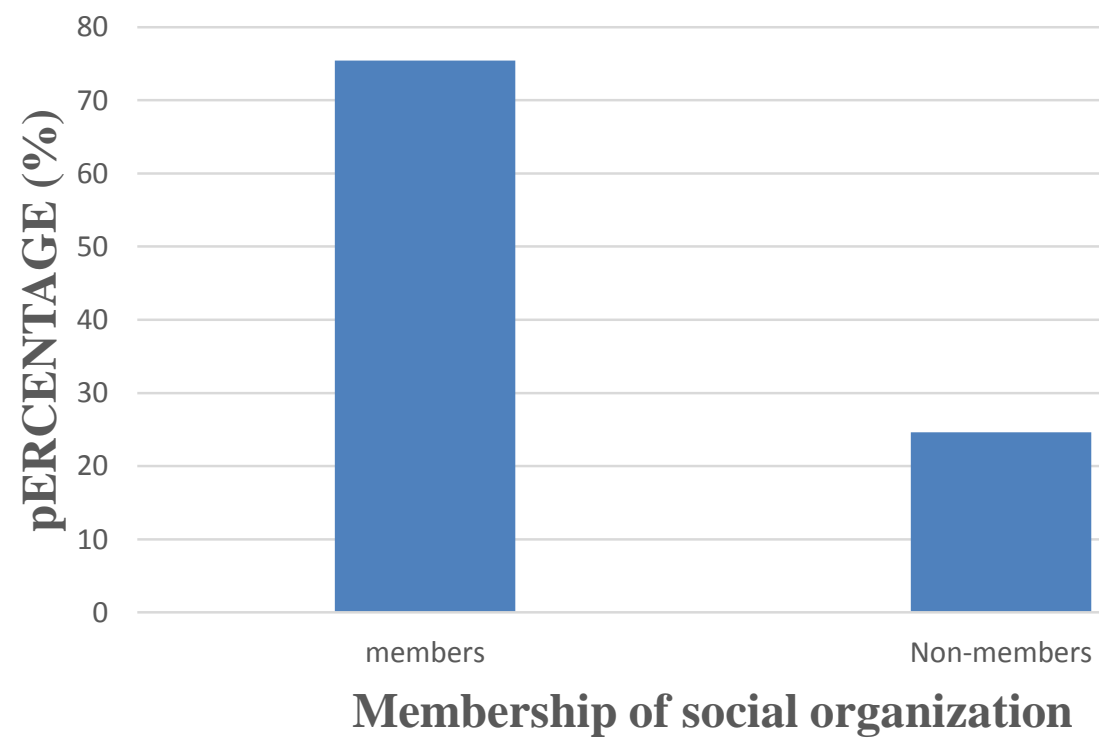

Fig1. Distribution of Respondents by Membership of Social Organization

Source: Field Survey Data, 2016 
Chikaire, J.U et al. "Effects of Use of Information and Communication Technologies (ICTs) on Farmers' Agricultural Practices and Welfare in Orlu Agricultural Zone of Imo State, Nigeria"

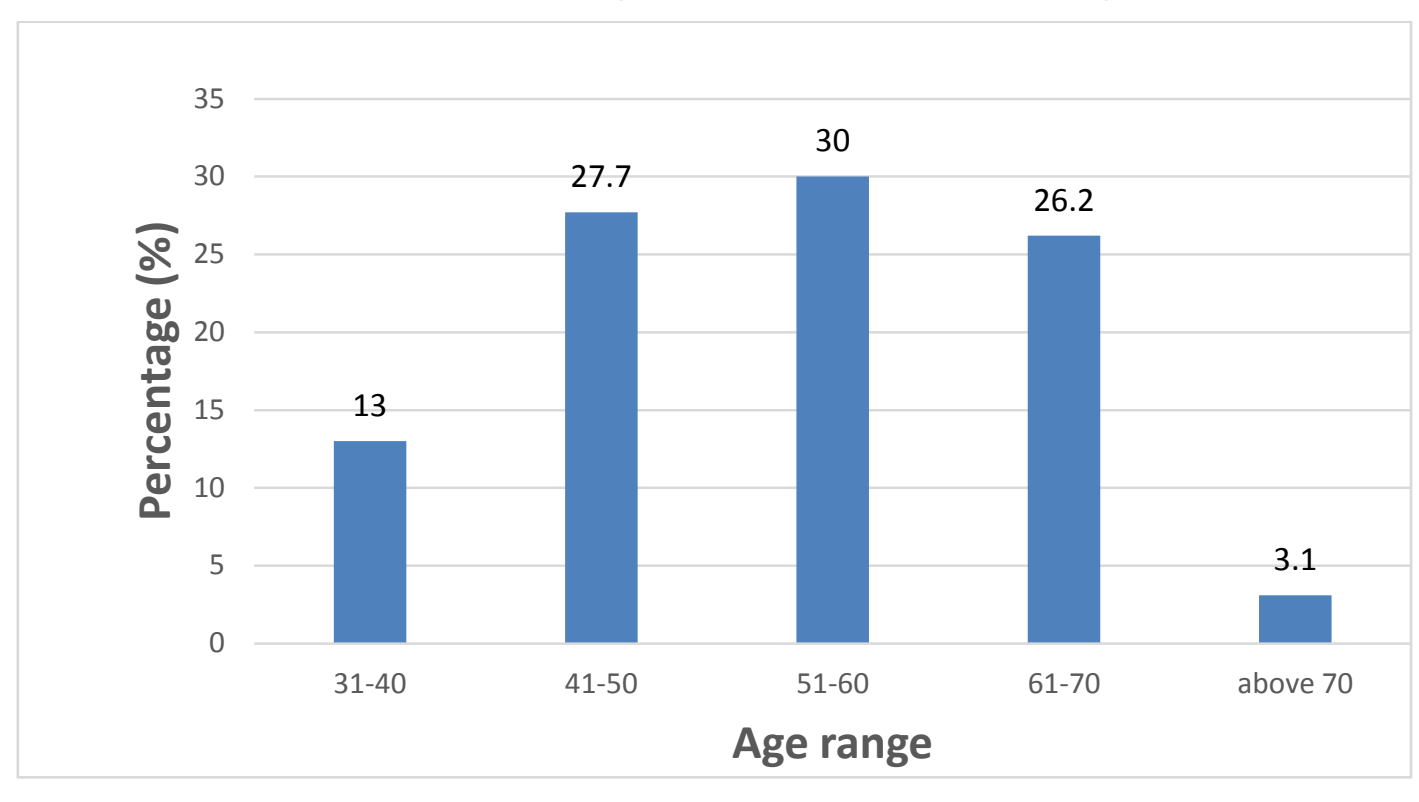

$\bar{X}=53$ years

Fig2. Age distribution of Respondents

\section{ICT Devices Available to the Farmers}

Table 2 showed that different ICT devices were available in the study area. It was discovered that radio, mobile phone and television are the most available ICT devices in the area since they had a percentages of 99.2, 97.7 and $76.1 \%$ respectively. This implies that these devices are the most sources of technological information and innovation dissemination in the area. This is in line with a study on ICT roles for poverty reduction among urban poor in Zimbabwe, where Bowora and Chazovachii (2010) revealed that the respondents in the informal sector bracket lacked the knowledge and exposure to ICTs other than cell phones, radios and televisions. Newspaper with $57.7 \%$ indicates that it is also readily available for use, since agricultural information can be sourced from it. Magazine, and computer with close average percentages of 30.8 and 29.2 respectively also indicates that information can be sourced through them, but they are not readily available since few respondents had computer in which they can source information. On other hand, the internet and e-mail users are $23.1 \%$ and $21.5 \%$ respectively which also shows that they are not readily available but to some extent, still serve as means of getting information. This could be due to high cost of subscription or poor network coverage. Digital camera and CD-ROM have the least percentages of 2.3 and 3.1 respectively. This shows that they are the least available ICT devices by which the farmers source information in the area. In all, the result shows that radio is the most readily available device and this agrees with (Sida, 2005) that radio is unique in that it is relatively inexpensive to set up, it is estimated that more than $50 \%$ of all households in developing countries have ready access to radio receivers, receiving broadcasts does not require literacy, and it can use indigenous languages even if the population served is small, this accounts for its usefulness on a regular basis.

Table2. Distribution of available ICT devices to the farmers

\begin{tabular}{|l|l|l|}
\hline Available ICT devices & $* *$ Frequency & Percentage (\%) \\
\hline Mobile phone & 127 & 97.7 \\
\hline Television & 99 & 76.1 \\
\hline Radio & 129 & 99.2 \\
\hline Computer & 38 & 29.2 \\
\hline CD-ROMs & 4 & 3.1 \\
\hline Internet & 30 & 23.1 \\
\hline Newspaper & 75 & 57.7 \\
\hline Magazine & 40 & 30.8 \\
\hline Digital camera & 3 & 2.3 \\
\hline E-mail & 28 & 21.5 \\
\hline
\end{tabular}

**Multiple Responses

Source: Field survey data 2016 
Chikaire, J.U et al. "Effects of Use of Information and Communication Technologies (ICTs) on Farmers' Agricultural Practices and Welfare in Orlu Agricultural Zone of Imo State, Nigeria"

\section{Effects of ICT Use on Agricultural Practices}

Table 3 showed the effects of ICT use on respondents agricultural practices. The respondents showed positive response (agree) to all the listed effects of use of ICTs. The respondents improved in the following areas; adoption of soil conservation practices $(\bar{x}=3.20)$, ability to adopt better land use practices $(\bar{x}=3.14)$, ability to use and apply manure/fertilizer $(\bar{x}=3.05)$, supply chain/risk management $(\bar{x}=2.95)$, better residue/organic matter management $(\bar{x}=2.85)$, ability to monitor pest/disease outbreak $(\bar{x}=2.83),(\bar{x}=2.82)$, to know effective planting strategy on steep slopes $(\bar{x}=2.82)$, improved/timely weeding $(\bar{x}=2.74)$, use of appropriate planting material $(\bar{x}=2.67)$, proper land preparation technique $(\bar{x}=2.71)$, planting seeds at right rate and date $(\bar{x}=2.58)$, planting at right depth/density ( $\bar{x}=3.01$ ), and improve crop and land rotation course $(\bar{x}=3.76)$. Thus, the findings agrees with the implication that good farming practices maximize chances of a good harvest. Digital soil maps give practitioners a good picture of soil fertility, vulnerability, and potential. Statistically testing soil maps against other data on human or policy variables (like demographics, land administration, farming practices, and climatic changes) allows researchers and others to explore causes of soil damage and forms of restoration.

Table3. Effects of Use of ICTs on Agricultural Practices.

\begin{tabular}{|l|l|l|}
\hline Effects on Agricultural Practices & Mean $(\overline{\boldsymbol{X}})$ & Standard Deviation (S.D) \\
\hline Ability to adopt soil conservation practices & 3.20 & 0.84 \\
\hline Ability to adopt better land use practices & 2.82 & 0.78 \\
\hline Better residue/organic matter management & 2.85 & 0.92 \\
\hline Ability to know how to store properly & 3.14 & 0.83 \\
\hline To know effective planting strategy on steep slopes & 2.82 & 0.91 \\
\hline Ability to monitor pest/disease outbreak & 2.83 & 0.95 \\
\hline Ability to use and apply manure/fertilizer & 3.05 & 0.88 \\
\hline Improved/timely weeding & 2.74 & 1.07 \\
\hline Supply chain/risk management & 2.95 & 0.85 \\
Use of appropriate planting material & 2.67 & 0.75 \\
Improve land preparation technique & 2.71 & 0.69 \\
Planting seeds at right depth/crop density & 3.01 & 1.05 \\
Planting appropriate seed rate/date & 2.58 & 0.59 \\
Improve crop and land rotation course & 3.76 & 0.89 \\
\hline
\end{tabular}

Source: Field survey data 2016 Decision Rule: Mean effect $(\bar{x}) \geq 2.50=$ Agree

Mean effect $(\bar{x})<2.50=$ Disagree

\section{Effects on Respondents Welfare}

Table 4 showed that use of ICTs have significant effects on the farmers' welfare as seen in the high mean response of the respondents. The effects included access to ready market $(\bar{x}=3.33)$, access to nutritious food (2.8), education of children $(\bar{x}=2.97)$, access to micro-credit $(\bar{x}=3.20)$ and reduce transportation/information cost $(\bar{x}=3.12)$. In accessing high-value markets, smallholder farmers need real time information on markets and prices. Through the information provided by the mobile platforms, farmers are able to know which markets to take their products to for better prices which will ultimately reflect in their profit levels. ICT interventions attract attention because they are more effective in communicating knowledge to farmers in rural areas and they facilitate access to markets. Farmers with more access to markets receive high output price, pay low input price, receive higher incomes and realize high gross margins than those with poor access to agricultural markets. Again, increase income $(\bar{x}=3.02)$, education of children $(\bar{x}=2.97)$, bought more equipment for farming ( $\bar{x}=2.91)$, access to nutritious food $(\bar{x}=2.86)$, bought more household items $(\bar{x}=2.78)$ and built more houses $(\bar{x}=2.68)$ were positive effects of ICT use. This means that robust positive results exist between use of ICT [mainly mobile phones] for information search and increased income among farmers. The farmers' incomes are expected to increase with the farmers access to real time information made available by the mobile platforms. This is because farmers can make better decisions due to their knowledge of prevailing prices, available markets, and there increased bargaining power. Other effects were increase yield $(\bar{x}=2.73)$, efficient supply chain $(\overline{\bar{x}}=2.65)$, reduced production wastage $(\bar{x}=3.02)$, improved farm processing/marketing $(\bar{x}=2.87)$ and finally, use of quality healthcare services $(\bar{x}=2.56)$. ICT use made the above possible and since providing 
Chikaire, J.U et al. "Effects of Use of Information and Communication Technologies (ICTs) on Farmers' Agricultural Practices and Welfare in Orlu Agricultural Zone of Imo State, Nigeria"

price information to farmers could be beneficial by increasing their bargaining power when they negotiate with traders, (Jaleta and Gardebroek, 2007) they should get better prices for their produce, which, in turn, should translate into higher consumption.

One of the factors impeding the magnitude of returns smallholder farmers make from their produce is the high transaction costs. Transaction cost in this case is the cost of doing business or cost of exchange between farmers and buyers. Lack of information between the farmer and the buyer makes trade more costly (Okello et al, 2012). In a study that compared transaction costs throughout an extended period, 15.2 percent of the total cost of farming was transactional, and of that, 70 percent was informational (De Silva and Ratnadiwakara 2008). It is therefore easy to understand how mobile phones can reduce farmers' transaction costs. Time costs, search and screening costs for buyers and transport costs of farmers are also reduced. ICT-based MIS(market information service) is expected to reduce these transactions costs by reducing the asymmetry of information and uncertainty related to trade

Table4. Effects of Use of ICTs on their welfare.

\begin{tabular}{|l|l|l|}
\hline Effects on their Welfare & Mean $(\overline{\boldsymbol{X}})$ & Standard Deviation (S.D) \\
\hline Access to ready markets & 3.33 & 0.71 \\
\hline Access to nutritious food & 2.86 & 0.88 \\
\hline Education of children & 2.97 & 0.96 \\
\hline Increase income & 3.02 & 0.93 \\
\hline Built more houses & 2.68 & 1.02 \\
\hline Bought more household items & 2.78 & 1.04 \\
\hline Bought more equipment for farming & 2.91 & 0.95 \\
\hline Use of quality healthcare services & 2.56 & 0.98 \\
\hline Access to micro-credit & 3.20 & 0.76 \\
\hline Reduces transportation/information cost & 3.12 & 0.86 \\
Increased yields & 2.73 & 0.65 \\
Efficient supply chains & 2.65 & 0.85 \\
Reduced production wastages & 3.02 & 0.78 \\
Improved farm processing/marketing & 2.87 & 0.65 \\
\hline
\end{tabular}

Source: Field Survey Data 2016

Decision Rule: Mean effect $(x) \geq 2.50=$ Agree, Mean effect $(x)<2.50=$ Disagree

\section{Constraints Affecting Respondents' Use of ICT Devices}

Entries in the table above shows that the most perceived constraints limiting respondents use of ICT device are; erratic power supply (98.5\%), low level of education (93.1\%), language barrier (92.3\%), lack of ICT skills (91.5\%), low income of farmers (88.5\%), unavailability of ICT centers $(82.3 \%)$ and high cost of ICT facilities (79.2\%). Other constraints that also affect the respondents' use of ICT devices include; poor benefit of using ICT (67.7\%), inadequate time for farmers (65.4\%), lack of ICT training (63.8\%), general lack of awareness on the importance of ICT in agriculture $(63.1 \%)$ and lack of exposure to ICT devices (46.2\%). This affirms the claims of FAO (2000), that the update and harnessing of information is limited by the lack of trained personnel or lack of access to know how. Meanwhile, the least constraints indicated by the respondents as regards to their use of ICT devices are; poor network coverage (30.0\%), lack of service shops in the area (20.0\%), lack of durable ICT devices (17.7\%), high cost of internet subscription (20.0\%) and broadcast at odd hours (14.6\%). This shows that all the perceived constraints listed above affect the respondents use of ICT devices however, some have huge effect while others pose less effect. Electricity and power supplies are absolute prerequisites to using contemporary ICT systems. Bertolini (2004) had earlier observed that several obstacles hinder ICTs usage in developing countries, especially in areas of access to telephone and electricity networks.

Table5. Constraints affecting their use of ICT devices

\begin{tabular}{|l|l|l|}
\hline Constraints & $* *$ Frequency & Percentage (\%) \\
\hline Erratic power supply & 128 & 98.5 \\
\hline Low level of education & 121 & 93.1 \\
\hline Language barrier & 120 & 92.3 \\
\hline Lack of ICT skills & 119 & 91.5 \\
\hline
\end{tabular}


Chikaire, J.U et al. 'Effects of Use of Information and Communication Technologies (ICTs) on Farmers' Agricultural Practices and Welfare in Orlu Agricultural Zone of Imo State, Nigeria"

\begin{tabular}{|l|l|l|}
\hline Low income of farmers & 115 & 88.5 \\
\hline Unavailability of ICT centers & 107 & 82.3 \\
\hline High cost of ICT facilities & 103 & 79.2 \\
\hline Inadequate time for farmers & 85 & 65.4 \\
\hline Age limit of farmers & 78 & 60.0 \\
\hline Lack of ICT training & 83 & 63.8 \\
\hline Lack of exposure to ICT facilities & 60 & 46.2 \\
\hline Poor network coverage & 39 & 30.0 \\
\hline Lack of durable ICT devices & 23 & 17.7 \\
\hline Lack of service shops in the area & 26 & 20.0 \\
\hline Broadcast at odd hours & 19 & 14.6 \\
\hline High cost of internet subscription & 26 & 20.0 \\
\hline Poor benefits in using ICT & 88 & 67.7 \\
\hline $\begin{array}{l}\text { General lack of awareness of the importance of ICT in } \\
\text { agriculture. }\end{array}$ & 82 & 63.1 \\
\hline
\end{tabular}

Source: Field survey data 2016

**multiple response

\section{CONCLUSION}

From the study, one can conclusively say that radio and mobile phone, followed by television were the most accessed and utilized ICTs among the respondents. There was a high perception of positive effects of ICT on agricultural practices and their welfare, however, the use of these ICT devices are limited by some factors. Therefore, there is need to encourage ICT user farmers in the area, by making available all that are necessary for successful ICT usage, including training in order to promote maximum gain and utilization of technological knowledge and information which will lead to improved farming practices, increased productivity as well as improved standard of living of the farmers. We recommend the following-

i. The rural dwellers should be given the requisite skills required for information management. They should be exposed to practical computer training for the enhancement of ICT use.

ii. Establishment of call centers to cater for those that prefer calling to texting is necessary and should be considered and developed if funds permit.

\section{REFERENCES}

[1] Anandajayasekeram, P., Workneh, S. and Hoekstra, R. (2008). "Concepts and practices in agricultural extension in developing countries: A source book." Washington DC, USA, Nairobi, Kenya, IFPRI (International Food Policy Research Institute), ILRI (International Livestock Research Institute).

[2] .Asiabaka, C.C. (2002). Agricultural Extension: A handbook for developing practitioners. Molysfem limited services

[3] Bertolini, R. (2004).Making Information and Communication Technologies work for Food Security in Africa. International Food Policy Research Institute's (IFPRI)2020 African Conference Brief 11 pp1-6. www.ifpri.org.

[4] Bowora, J. and Chazovachii, B. (2010). The role of information and communication technologies in poverty reduction in Zimbabwe: An analysis of the urban poor in Harare. Int. J.Polit. Good. Govern. 1, 1-3.

[5] Central Bank of Nigeria, (2000). The changing structure of the Nigerian Economy and Implication for Development, Lagos: Realm Communications Ltd, August.

[6] De Silva, H., and D. Ratnadiwakara. 2008. - Using ICT to Reduce Transaction Costs in Agriculture through Better Communication: A Case-Study from Sri Lanka.ll LIRNEasia, Edgerton, M. D. (2009). "Increasing Crop Productivity to Meet Global Needs for Feed, Food, and Fuel. "Plant Physiology 149:7-13.

[7] FAO (Food and Agricultural Organization),(2000). Report of the First Consultation on Agricultural Information Management, Rome 5-7 June 2000. Rome: Food and Agricultural Organization of the United Nations 
Chikaire, J.U et al. 'Effects of Use of Information and Communication Technologies (ICTs) on Farmers' Agricultural Practices and Welfare in Orlu Agricultural Zone of Imo State, Nigeria"

[8] IICD (International Institute for Communication and Development),(2006).ICTs for Agriculture Livelihoods: Impact and Lessons Learned from IICD Supported Activities. The Hague: IICD. http:// www.iicd.org/files/IICD-agri-impact-2006.pdf, accessed April 2011.

[9] IMSG, (2010).Education in Imo State. Imo State, Nigeria: Ministry of information, Owerri, Imo State Government.

[10] Jaleta, M. and Gardebroek, C. (2007). "Farm-gate tomato price negotiations under asymmetric information" Agricultural Economics, 36(2), 245-25.

[11] Kaushik, P.D. (2004). "Information technology and Broad-Based Development: Preliminary Lessons from North India." World Development.

[12] Munyua, H. (2008): ICTs and small-scale agriculture in Africa: A scoping study.

[13] National Population Commission (NPC) (2006). Official Population Report of South East Nigeria.

[14] Nwagwu, W.E and Opeyemi, S. (2015) ICT Use in Livestock Innovation Chain in Ibadan City in Nigeria. Advances in Life Science and Technology, 32.

[15] Okello J. J., Ogutua S. O., Otiena D. J. (2013) Impact of Information and Communication Technology-based Market Information Services on Smallholder Farm Input Use and Productivity: The Case of Keny. Proceedings from the 4th International Conference of the African Association of Agricultural Economists (ICAAAE)

[16] Ogen, O. (2007). The Agricultural Sector and Nigeria's Development: A Comparative Perspective from the Brazilian Agro-industrial Economy 1960- 1995. Nebula, March.

[17] Richardson, D. (1997). "The Internet and Rural and Agricultural Development: An Integrated Approach." FAO.

[18] Swanson, B.E. and Rajalahti, R. (2010).Strengthening Agricultural Extension and Advisory Systems: procedures for Assessing, Transforming and Evaluating Extension Systems, The International Bank for Reconstruction and Development/The World Bank, Washington, pp. 98127.

[19] UNDP (2005)."Global E-Government Readiness Report: From E-Government to Inclusion". United Nations, New York.

[20] World Bank, (2007).World Development Report 2008: Agriculture for Development. Washington, DC 